Билоус Наталия, Новохатская Наталия. Неологизмы как средство отображения современного образа жизни носителей английского языка. Статья определяет понятие миллениалов как поколение, рожденное после 1981 года, и которое характеризуется глубокой зависимостью от цифровых технологий, социальными и экономическими проблемами, обеспокоеностью вопросами загрязнения окружающей среды, проблемами социального неравенства и дискриминации. Другими терминами для обозначения этого поколения являются: поколение Y, NEXT, Селфи, эхо-бумеры, сетевое или цифровое поколение, чем подчеркивается глубокая зависимость миллениалов от цифровых технологий. Именно это поколение активно влияет на изменение лексического состава языка сквозь призму своей языковой ментальности, что и приводит к появлению неологизмов (слов или словосочетаний, используемых в языке в определенный период для обозначения нового или уже существующего понятия в новом значении, которое осознается носителями языка). В этом исследовании неологизмы классифицированы по следующим тематическим группам: 1) способы преодоления стресса (лексемы и словосочетания, обозначающие способы восстановления душевного равновесия в связи с недовольством результатами социальной и профессиональной деятельности, невозможностью решить поставленные задачи, нехваткой времени, отсутствием возможности эмоциональных проявлений): а) методика, б) животное, в) человек; 2) эффективный тайм-менеджмент (неологизмы для обозначения быстрого темпа жизни, постоянного дефицита времени и необходимости рационального планирования) 3) здоровый образ жизни (лексические единицы для обозначения сознательных подходов к питанию, новых видов спорта и отдыха): а) способ питания, б) виды спорта, в) способы отдыха; 4) взаимоотношения (новообразования, которые отражают демократические принципы, борьбу с гендерными стереотипами, важность индивидуальности и самовыражения): а) принципы воспитания детей, б) принципы взаимоотношений мужчина / женщина, в) борьба с предвзятостями; 5) жилищные условия (единицы для обозначения экономии на жилой площади, приоритетности инфраструктуры и района, возможности дистанционной работы, энергоэффективности и переработки отходов); 6) отношение к окружающей среде (неологизмы для обозначения способов защиты окружающей среды).

Ключевые слова: миллениалы, неологизм, тематические группы, языковые изменения.

Bilous Natalia, Novokhatska Natalia. Neologisms as Means to Reflect Native English Speakers' Modern Way of Life. The present article defines the notion and concept of millennials as a generation born after 1981 and characterizes it as a generation with a deep dependence on digital technologies, social and economic problems that is concerned with problems of environmental pollution, social inequality and discrimination. Other terms to denote this generation are: generation Y, NEXT, Selfie, echo boomers, network or digital generation, which emphasize deep dependence of millennials on digital technologies. It is this generation that actively influences changes in the lexical structure of the English language via their linguistic mentality. This processes lead to the emergence of neologisms (words or compounds used in a language in a certain period to refer to a new or existing concept in a new meaning, which are understood by native speakers). Based on the list of neologisms from the Cambridge Dictionary this study has classified them into the following thematic groups: 1) ways of overcoming stress (lexemes and phrases, denoting ways to restore mental balance caused by dissatisfaction with the results of social and professional activity, inability to solve tasks, lack of time and opportunities): a) methods, b) animal, c) human being; 2) effective time management (neologisms to indicate a fast pace of life, a constant shortage of time and the need for rational planning); 3) healthy lifestyle (lexical units denoting conscious approaches to eating, new sports and leisure time activities): a) diet, b) sports, c) leisure time activities; 4) relationships (new words reflecting democratic principles, overcoming gender stereotypes, importance of individuality and self-expression): a) principles of parenting, b) principles of relations between men and women, c) overcoming gender inequality; 5) living conditions (units which emphasize efforts to economize on accommodation, priority of infrastructure and district, remote work opportunities, energy efficiency and waste recycling); 6) attitude to the environment (neologisms designating environmental changes and ways to protect and enhance the environment to prevent risk of harm to human health).

Keywords: millennials, neologism, thematic groups, language changes.

DOI: https://doi.org/10.32782/2410-0927-2020-12-3

УДК 811.111 '42

Валентина Бойчук, Наталія Сфремова

\title{
ОСОБЛИВОСТІ ЦДЕНТИФІКАЦЇ̈ ПЕСИМІЗМУ ПЕРСОНАЖА В ТЕКСТІ ХУДОЖНЬОГО ТВОРУ (НА МАТЕРІАЛІ АНГЛІЙСЬКОЇ МОВИ)
}

Стаття присвячена висвітленню особливостей ідентифікації песимізму персонажа в тексті художнього твору. Художній текст є узагальненим образним відображенням дійсності у всьому різноманітті ії індивідуальносоціальних виявів. Оскільки аналізовані фрагменти художніх творів є стилізованим мовленням, розглядаємо художній текст як відображену реальність, що експлікує окремі фрагменти дійсності та фіксує реальні комунікативні ситуації, набуваючи при цьому певного прагматичного потенціалу. Аналіз лексичного контексту дозволив виявити набір мовних засобів, які безпосередньо або опосередковано вказують на песимістичні диспозиції, атрибуції, настрій або когнітивні стратегії персонажа художнього твору.

(C) Бойчук В., Сфремова Н., 2020 
Встановлено, що безпосередніми індикаторами песимізму персонажа в тексті художнього твору є мовні одиниці, які містяться в мові персонажів, авторських ремарках та авторських описах в англомовних художніх текстах. Сюди належать лексичні та фразеологічні одиниці на позначення песимізму.

Виявлено, що повна ідентифікація песимізму персонажа художнього твору здійснюється за допомогою лексеми pessimism і похідних одиниць pessimist, pessimistic, pessimistically, які вказують на особливості індивідуальної та соціальної поведінки індивіда. Прикметникові лексичні одиниці, які позначають якісні ознаки песимізму, є засобами часткової ідентифікації песимізму персонажа художнього твору.

Фразеологічні одиниці, які влучно передають психологічний стан персонажа, виражають його емоції, почуття, переживання і вказують на оцінне ставлення до навколишньої дійсності, у конкретних комунікативних умовах є потужним засобом мовленнєвої реалізації песимістичного світобачення. Серед фразеологічних одиниць, що ідентифікують песимізм персонажа в тексті художнього твору, є власне фразеологізми та паремії.

Опосередкованими індикаторами песимізму персонажа є контекстуальні маркери песимізму - фрагменти художнього тексту, в яких за допомогою мовних засобів, що вирізняються негативно-оцінною семантикою своїх елементів, фіксуються, підтверджуються, уточнюються, доповнюються і пояснюються причини, аспекти, наслідки та способи вияву песимізму персонажа художнього твору.

Ключові слова: песимізм, персонаж, художній твір, лексичний контекст, ідентифікація.

Вступ. Особистість як персонаж художнього твору виявляє себе за допомогою мовленнєвої діяльності, результатом якої $є$ побудова персонажного дискурсу, “що виокремлюється на тлі нарації і через те є підпорядкованим плану дискурсу наратора” [1, с. 49]. Персонажі, які існують у типізованому світі художнього тексту, - це максимально узагальнені моделі реальних мовних особистостей [3, с. 6]. Персонаж художнього твору, що демонструє песимістичні диспозиції, атрибуції, настрій або застосовує стратегію захисного песимізму, $є$ наріжним каменем побудови песимістичного персонажного дискурсу. Песимістичний дискурс представлений комплексною системою лексичних, фразеологічних, синтаксичних, стилістичних i прагматичних засобів репрезентації песимістичного світобачення персонажа [4, с. 161]. Відповідь на питання - які з цих засобів є мовними індикаторами песимізму персонажа в тексті художнього твору, є метою пропонованої статті. Ця мета передбачає виконання таких завдань: 1) виявити набір мовних засобів, які безпосередньо або опосередковано вказують на песимізм персонажа в художньому творі; 2) з'ясувати особливості повної та часткової ідентифікації песимізму персонажа художнього твору; 3) розкрити потенціал фразеологічних одиниць як мовних засобів ідентифікації песимізму персонажа; 4) визначити функції контекстуальних маркерів песимізму в тексті художнього твору.

Матеріалом дослідження слугували англомовні художні твори XX-XXI століть. Художній текст є узагальненим образним відображенням дійсності у всьому різноманітті ії індивідуальносоціальних виявів. Усвідомлюючи той факт, що аналізовані фрагменти художніх творів $є$ не прямим відображенням комунікації, а стилізованим мовленням, розглядаємо художній текст як відображену реальність, що експлікує окремі фрагменти дійсності та фіксує реальні комунікативні ситуації, набуваючи при цьому певного прагматичного потенціалу [2, с. 63-64].

Методи та методики дослідження. Для досягнення мети і розв'язання поставлених завдань було використано загальнонаукові (індукцію, дедукцію, аналіз, синтез) та спеціальні методи дослідження (аналіз словникових дефініцій - для встановлення закріплених у мовному узусі засобів на позначення песимізму; компонентний аналіз - для визначення семантичної структури лексичних і фразеологічних одиниць на позначення песимізму; контекстуальний аналіз - для дослідження функційного аспекту мовних засобів репрезентації песимізму персонажа в тексті художнього твору). Під час аналізу опираємось на поняття внутрішнього (мовного, вербального) контексту, який є симбіозом лексичних, синтаксичних і стилістичних сигналів.

Результати та дискусії. Лексичний контекст $є$ тим “фільтром, який елімінує та конкретизує значення слова, створює навколо нього певне коло асоціацій” [5, с. 21] і визначає набір засобів, що безпосередньо або опосередковано вказують на якісні ознаки песимізму.

Безпосередніми індикаторами песимізму персонажа в тексті художнього твору $є$ мовні одиниці - ідентифікатори песимізму, які містяться в мові персонажів, авторських ремарках та авторських описах в англомовних художніх текстах. Сюди належать лексичні та фразеологічні одиниці на позначення песимізму.

Опосередкованими індикаторами песимізму персонажа $\epsilon$ контекстуальні маркери песимізму (далі - КМП) - фрагменти художнього тексту, в яких за допомогою мовних засобів, 
що вирізняються негативно-оцінною семантикою своїх елементів, уточнюються, доповнюються і пояснюються причини, аспекти, наслідки та способи вияву песимізму.

Повна ідентифікація песимізму персонажа художнього твору здійснюється за допомогою лексеми pessimism і похідних одиниць pessimist, pessimistic, pessimistically, які вказують на особливості індивідуальної та соціальної поведінки індивіда. Як правило, досліджувані фрагменти містять КМП, за допомогою яких здійснюється вказівка на реалізацію у мовленні якісних ознак песимізму. Характерною $є$ наявність контекстуальних маркерів, які вказують на узуальність або актуальність вияву песимістичного світобачення і таким чином звужують його до диспозиційного, ситуативного чи захисного песимізму. Подані приклади це засвідчують:

"I suppose I ought to enjoy the joke of what's going on here,"/.../ "but somehow it doesn't amuse me. Pessimism on the contrary possesses me and cynicism deeply engages. I positively feel my own flesh sore from the brass nails in Neil Paraday's social harness”" [9, c. 112].

У цьому висловленні КМП “it doesn't amuse me" та "I positively feel my own flesh sore" доповнюють песимістичну автохарактеризацію мовця, лексичним ідентифікатором якої $\epsilon$ лексична одиниця (далі - ЛО) pessimism, вказівкою на сум і страждання, що їх переживає персонаж, таким чином актуалізуючи в мовленні базову ознаку песимізму "сум" і суміжну ознаку - “страждання". Контекстуальний маркер “possesses me” відображає ситуативність песимізму як настрою.

"A pessimist. I'm a new sort of pessimist. I think I'm the sort that will go down."

"Why not? But you must -."

"No! I am the panurgic - pessimist, drunken with the laughing-gas of the Abyss: I gaze upon squalor and idiocy, and the more I see them the more I like them" [12, c. 13].

Фокусом повної песимістичної ідентифікації персонажа є ЛО pessimist, доповнена вказівкою на негативні очікування (КПМ “will go down”) та іронічне ставлення до наявного стану речей (КМП "I gaze upon squalor and idiocy, and the more I see them the more I like them"). Диспозиційний характер песимістичного світобачення в аналізованому фрагменті підкреслено за допомогою контекстуального маркера "a new sort”.

"Perhaps I am always a trifle the pessimist", said Pascoe, putting back his spectacles. "But maybe that is one of the necessary characteristics of a b-banker. I do not like this war and what it is doing to us, even though it may bring a temporary prosperity" [11, c. 81].

Наведений текстовий фрагмент є прикладом актуалізації когнітивної стратегії захисного песимізму. Постійна готовність до негативного сценарію розвитку подій свідчить про реальну оцінку персонажем своїх можливостей з метою уникнення необгрунтованого ризику. Лексичним індикатором повної ідентифікації песимізму персонажа є ЛО pessimist. КМП "I do not like this war and what it is doing to us, even though it may bring a temporary prosperity" доповнює песимізм персонажа вираженням незадоволення та негативного ставлення до ситуації, що описується.

Часткова песимістична ідентифікація персонажа художнього твору здійснюється за допомогою переважно прикметникових ЛО, які позначають базові, суміжні та супутні якісні ознаки песимізму. КМП, виявлені в тексті, фіксують, підтверджують, уточнюють і доповнюють актуалізацію песимістичного світобачення персонажа. Наведемо приклад:

"As I sit here among my books in this special room that I have enjoyed so much over the year, I am despondent. The "winter of despair" is here. We have nothing before us except uncertainty and fear" $[8$, c. 9$]$.

У запропонованому текстовому фрагменті часткова ідентифікація песимізму персонажа художнього твору здійснюється за допомогою лексеми despondent. У семантичній структурі цієї ЛО зафіксовано семи песимізму, які вказують на базові (“сум”, “безнадія”, “нещастя”), суміжну (“пригніченість”) та супутню (“розчарування”) ознаки песимізму. КМП “winter of despair” i “we have nothing before us except uncertainty and fear" виражають відчай, невпевненість, негативні очікування і страх. На ситуативність песимізму вказує контекстуальний маркер "As I sit here among my books /.../".

Фразеологізми, які влучно передають психологічний стан мовця, виражають його емоції, почуття, переживання і вказують на оцінне ставлення до навколишньої дійсності, у конкретних комунікативних умовах є потужним засобом мовленнєвої реалізації песимістичного 
світобачення. Серед фразеологічних одиниць (далі - ФО), які ідентифікують песимізм персонажа в тексті художнього твору, є власне фразеологізми та паремії, які “відповідають багатьом критеріям фразеологізмів - відтворюються в готовому вигляді, мають постійну граматичну структуру та компонентний склад" [6, с. 148].

Як засоби-ідентифікатори песимізму персонажа ФО супроводжуються КМП, що підтверджують, уточнюють і доповнюють якісні ознаки песимізму:

"Everything I had once believed seems to be in question. I somehow could never buy into the belief that so much of religious doctrine surrounded the concept of sin and punishment - the wrath of God. And how much fear has been used to motivate in religion. When you are good, you know that you can't keep it up forever, so you wait for the other shoe to drop. Then there it is - staring you right face - sin. It makes me squeamish. And for some reason, it never added up for me" [10, c. 114].

ФО "wait for the other shoe to drop", відображаючи внутрішній стан персонажа-песиміста, актуалізує в тексті базову ознаку песимізму “негативні очікування" (To wait for the other shoe to drop - to wait for something bad to happen). Ця ж ознака акцентується за допомогою КМП "уоu can't keep it up forever". КМП "Everything I had once believed seems to be in question" вказує на мовленнєву реалізацію базової ознаки песимізму "невіра". КМП "squeamish" підкреслює вразливість персонажа в ситуації, 3 якої нелегко знайти вихід, таким чином вказуючи на мовленнєву експлікацію ситуативного песимізму.

Паремії своєю образністю, метафоричністю, клішованістю й емоційністю підкреслюють песимістичне світобачення персонажа. Прозорість актуалізації зазначених базових ознак песимізму сприяє конкретизації окремих аспектів мовленнєвої реалізації песимізму. Наведемо приклад:

Over coffee, I asked him what the best play he had produced was. Without hesitation, he said, "The one I have just completed. Yeats's version of Oedipus has more wisdom than any play I have encountered."

"Why?” I only vaguely knew the play.

"The last two lines are extraordinary. "Call no man fortunate that is not dead. The dead are free from pain. In other words, no man is happy until he dies."

"That's pretty bleak, John."

"Ah, but don't you see - he was living in dangerous times. I think what he means is that we just don't know what is round the corner. What is to come. That you cannot rest on your laurels until the moment you die. Very sobering, don't you think? After all, none of us knows what lies ahead"' [7, c. 47].

У наведеному фрагменті песимізм співрозмовників експлікується паремійною одиницею "call no man happy till he dies/is dead" (however happy somebody seems to be, there is always the risk that he or she will be struck by sorrow or misfortune), яка має сему песимізму "he or she will be struck by sorrow or misfortune” й актуалізує у мовленні базову ознаку “негативні очікування". Ця ж ознака акцентується КМП “we just don't know what is round the corner”, "you cannot rest on your laurels until the moment you die", "none of us knows what lies ahead”. КМП "we just don't know what is round the corner", вказуючи на невпевненість персонажа, реалізує в тексті художнього твору відповідну базову ознаку песимізму. КМП "The dead are free from pain" $\epsilon$ засобом мовленнєвої актуалізації базової ознаки песимізму “біль". КМП "pretty bleak” і “very sobering”, вказуючи на безперспективність майбутнього, посилюють песимізм діалогу.

Висновки. Семантичний простір тексту художнього твору акумулює мовні засоби, які безпосередньо або опосередковано ідентифікують песимістичне світобачення персонажа. Лексичними засобами повної ідентифікації песимізму персонажа є лексеми pessimism, pessimist, pessimistic, pessimistically, у семантичній структурі яких наявні компоненти, що вказують на філософські, психологічні та соціально-когнітивні аспекти цього феномену. Прикметникові лексичні одиниці, які позначають якісні ознаки песимізму, є засобами часткової песимістичної ідентифікації персонажа художнього твору. Фразеологічні одиниці із семантикою песимізму влучно передають психологічний стан персонажа, виражають його емоції, почуття, переживання і вказують на оцінне ставлення до навколишньої дійсності. Контекстуальні маркери песимізму, які фіксують, підтверджують, уточнюють і доповнюють мовленнєву актуалізацію песимістичного світобачення, $\epsilon$ опосередкованими індикаторами песимізму персонажа 
художнього твору. Зважаючи на результати цього дослідження, перспективним вважаємо опис стилістичних засобів репрезентації песимістичного світобачення персонажа.

\section{References}

1. Bekhta, Ivan. 2004. Dyskurs naratora v anhlomovniy prozi. Kyiv: Hramota.

2. Belozerova, Aleksandra. 2016. "Yazikovaya reprezentatsyya kommunykatyvnoho povedenyya ynytsyatora konflykta v anhloyazychnom khudozhestvennom tekste (henderniy aspekt)". PhD diss., Ivanovo.

3. Bondarenko, Yana. 2002. "Dyskurs aktsentuyovanykh movnykh osobystostey: komunikatyvno-kohnityvnyy aspekt (na materiali personazhnoho movlennya v suchasniy amerykans'kiy khudozhniy prozi)". PhD diss., Kyiv.

4. Boychuk, Valentyna. 2019. "Reprezentatsiya fenomenu pesymizmu v suchasniy anhliyskiy movi". PhD diss., Lviv.

5. Dudok, Roman. 2013. "Kontekstni ta intehralni indykatory u traktuvanni znachennya". Visnyk Zhytomyrskoho derzhavnoho universytetu im. I. Franka. Filolohichni nauky 68: 21-23.

6. Kocherhan, Mykhaylo. 2006. Zahalne movoznavstvo: pidruchnyk. Kyiv: Vydavn. tsentr «Akademiya».

7. Howe Jeremy. 2012. Mummydaddy. Pan Macmillan.

8. Jackson, Grace L. 2011. Woman Alone. AuthorHouse.

9. James, Henry. 2013. The Aspern Papers and Other Stories. Oxford: Oxford University Press.

10. Perron, Mari. 2014. Grace: Finding the Light. Take Heart Publications.

11. Winston, Graham. 2011 The Black Moon: A Novel of Cornwall 1794-1799. Pan Macmillan.

12. Wyndham, Lewis. 2010. Tarr. Oxford: OUP.

Бойчук Валентина, Ефремова Наталия. Особенности идентификации пессимизма персонажа в тексте художественного произведения (на материале английского языка). Статья посвящена рассмотрению особенностей идентификации пессимизма персонажа в тексте художественного произведения. Художественный текст является обобщенным образным отражением действительности во всем многообразии ее индивидуальносоциальных проявлений. Поскольку анализируемые фрагменты художественных произведений являются стилизированной речью, мы рассматриваем художественный текст как отраженную реальность, которая эксплицирует отдельные фрагменты действительности и фиксирует реальные коммуникативные ситуации, приобретая при этом определенный прагматический потенциал. Анализ лексического контекста позволил выявить языковые средства, которые прямо или косвенно указывают на пессимистические диспозиции, атрибуции, настроение или когнитивные стратегии персонажа художественного произведения.

Установлено, что непосредственными индикаторами пессимизма персонажа в тексте художественного произведения являются языковые единицы, содержащиеся в речи персонажей, авторских ремарках и авторских описаниях в англоязычных художественных текстах. Сюда относятся лексические и фразеологические единицы для обозначения пессимизма.

Выявлено, что полная идентификация пессимизма персонажа художественного произведения осуществляется с помощью лексемы pessimism и производных единиц pessimist, pessimistic, pessimistically, указывающих на особенности индивидуального и социального поведения индивида. Атрибутивные лексические единицы, обозначающие качественные признаки пессимизма, являются средствами частичной идентификации пессимизма персонажа художественного произведения.

Фразеологические единицы, которые точно передают психологическое состояние персонажа, выражают его эмоции, чувства, переживания, и указывают на оценочное отношение к окружающей действительности, в конкретных коммуникативных условиях являются мощным средством речевой реализации пессимистического мировоззрения. Фразеологическими единицами, которые идентифицируют пессимизм персонажа в тексте художественного произведения, являются собственно фразеологизмы и паремии. Опосредованными индикаторами пессимизма персонажа выступают контекстуальные маркеры пессимизма - фрагменты художественного текста, в которых с помощью языковых средств с негативно-оценочной семантикой фиксируются, подтверждаются, уточняются, дополняются и объясняются причины, аспекты, последствия и способы проявления пессимизма персонажа художественного произведения.

Ключевые слова: пессимизм, персонаж, художественное произведение, лексический контекст, идентификация.

Boichuk Valentyna, Yefremova Nataliia. Identification of the Character's Pessimism in English Literary Texts. The article highlights the ways pessimistic features of the characters may be identified in English literary texts. Literary text is a generalized figurative reflection of reality in all its diversity of individual and social manifestations. Since the analyzed fragments of fiction are stylized speech, we consider the literary text to be a reflected reality that explicates certain fragments of reality and captures real communicative situations, acquiring at the same time a certain pragmatic potential. The analysis of the lexical context has revealed a set of language means that directly or indirectly indicate the pessimistic dispositions, attributions, mood or cognitive strategies of the literary character.

It has been found out that the language units contained in the speech of the characters, author's remarks and author's descriptions in English literary texts are direct indicators of the pessimism of literary characters. These include lexical and phraseological units designating pessimism.

It has been revealed that the complete identification of the literary character's pessimism is carried out with the help 
of the lexical unit pessimism and its derived units pessimist, pessimistic, pessimistically, which indicate the characteristics of individual and social behavior of the personage. Adjectival lexical units, which designate the qualitative features of pessimism, are the means of partial identification of the pessimism of literary characters.

Phraseological units which accurately convey the psychological state of the character, express his/her emotions, feelings, experiences and indicate the evaluative attitude to the reality, are powerful means of speech realization of the pessimistic world view in specific communicative conditions. Phraseological units that identify pessimism of the literary character are phraseological units proper and proverbs.

Indirect indicators of the literary character's pessimism are contextual markers of pessimism - fragments of literary texts, in which with the help of linguistic means, characterized by negative semantics of their elements, causes, aspects, consequences and ways of expressing pessimism are captured, confirmed, clarified, completed and explained.

Key words: pessimism, character, literary text, lexical context, identification.

DOI: https://doi.org/10.32782/2410-0927-2020-12-4

УДК 811.111-26

Галина Вальчук

\section{ПРАГМАТИЧНА ФУНКЦЙНІСТЬ НЕОЛОГІЗМІВ У АНГЛОМОВНИХ МЕДІЙНИХ ТЕКСТАХ}

Стаття присвячена актуальним проблемам функціонування та перекладу неологізмів у медійних текстах сучасної англомовної преси. В ході дослідження дано визначення поняття «медіатекст». Охарактеризовані стилістичні особливості англомовних медійних текстів. Відзначено, що мова англомовних медійних текстів має певні особливості та спрямування на окремі категорії читачів. В ході аналізу англомовних медіа доведено пряму залежність між ступенем складності підібраних мовних засобів та соціокультурними специфічними рисами цільової аудиторії.

Підкреслено, що переважну частину специфічної лексики в англомовних медіа складає суспільно-політична лексика. Перед політичними текстами стоїть завдання водночас і чітко передавати події світу політики, і не надто ускладнювати та перевантажувати повідомлення різноманітними термінами, які б заважали його розумінню. Відтак журналісти часто вдаються до вживання неологізмів.

Розглянуто поняття неологізмів та їх типологію. Відзначено, що існують різні параметри визначення терміна "неологія": процес створення нових лексичних одиниць будується відповідно до звичайних механізмів творчого процесу в розвитку мови; теоретичне і прикладне дослідження створення лексичних одиниць, способи утворення слів, критерії визнання, прийняття і поширення неологізмів, соціокультурні аспекти неології; систематично організована діяльність інститутів для обліку, створення, запису, поширення і впровадження неологізмів у чіткі рамки мовної політики; встановлення нових терміносистем і недавно створених галузей, що мають прогалини в термінології і вимагають іï впровадження; лексикографічна система відносин зі словниками виходить 3 двох аспектів: використання словника як фільтруючого засобу з визнання неологізмів і аналіз їх обробки всередині словників.

Розглянуто функційність неологізмів у медіатексті. Результати аналізу дають змогу зробити висновки, що неологізми досить поширені в газетних текстах, і це знаходить своє відображення в статтях різної тематики (економічної, ділової, розважальної, молодіжних газетах та ін.), створюючи в кожній із них свій стилістичний ефект. Відзначено, що передача неологізмів українською мовою здійснюється із залученням таких способів перекладу, як уподібнення, описовий переклад, калькування, транскрибування, транслітерація.

Ключові слова: лексика, неологізм, переклад, медіа, медіатекст.

Вступ. Однією з актуальних проблем сучасного мовознавства залишається дослідження співвідношення мови та культури, оскільки мова $є$ дзеркалом культури, в якому відбивається суспільна самосвідомість, спосіб життя, традиції, мораль, система цінностей і світогляд. Протягом останніх десятиліть у світі, зокрема в англомовних країнах, увагу привертає масштабний процес неологізації мови, тобто витворення в ній нових слів, що позначають новітні явища дійсності, які до того не мали слів для свого позначення в мові. Не $\epsilon$ винятком і сучасна англійська мова.

Актуальність теми роботи зумовлена інтересом до дослідження новоутвореної лексики в сучасній англійській мові, що, у свою чергу, пояснюється зростаючими процесами глобалізації та міжнародної інтеграції і співпраці в суспільстві. Особливу увагу в цьому аспекті привертає мова 3MI, що активно фіксує появу новотворів та використовує їх у медійних текстах різного спрямування.

Мета дослідження - охарактеризувати закономірності функціонування та перекладу

(C) Вальчук Г., 2020 